\title{
УДОСКОНАЛЕННЯ ПРОЦЕСУ РОЗРОБЛЕННЯ I ВПРОВАДЖЕННЯ ІНФОРМАЦЙНИХ СИСТЕМ УПРАВЛІННЯ ОРГАНІВ МІСЦЕВОГО САМОВРЯДУВАННЯ (НА ПРИКЛАДІ ЛЬВІВСЬКОЇ МІСЬКОЇ РАДИ)
}

\section{IMPROVING THE PROCESS OF DEVELOPMENT AND IMPLEMENTATION OF INFORMATION MANAGEMENT SYSTEMS OF LOCAL GOVERNMENTS (ON THE EXAMPLE OF LVIV CITY COUNCIL)}

\author{
Ванькович Любомир Ярославович \\ кандидат економічних наук, \\ Національний університет «Львівська політехніка» \\ ORCID: https://orcid.org/0000-0001-8776-8511 \\ Гриценяк Соломія Романівна \\ студентка, \\ Національний університет «Львівська політехніка» \\ ORCID: https://orcid.org/0000-0002-3367-7662 \\ Vankovych Liubomyr, Hrytseniak Solomiia \\ Lviv Polytechnic National University
}

\begin{abstract}
Стаття присвячена актуальним питанням процесу розроблення і впровадження інсормаційних систем управління. Окреслено особливості розроблення інорормаційних систем управління для органів місцевого самоврядування. На прикладі Львівської міської ради розкрито відмінність етапів створення цих систем в частині вивчення об'єкту управління, аналізування схем комунікацій, декомпозиції та реінжинірингу бізнеспроцесів територіальних громад. Побудовано алгоритм реалізації сценарію розроблення та впровадження (модернізації) інсрормаційної систем управління. Проаналізовано міждержавний стандарт «Інформаційна технологія. Комплекс стандартів на автоматизовані системи. Автоматизовані системи» щодо втрати чинності та запропоновано зміни з врахуванням особливостей органів місцевого самоврядування.
\end{abstract}

Ключові слова: інфрормаційна система управління, схема комунікацій, бізнес-процес, орган місцевого самоврядування, Львівська міська рада.

Статья посвящена актуальным вопросам процесса разработки и внедрения информационных систем управления. Обозначены особенности разработки информационных систем управления для органов местного самоуправления. На примере Львовского городского совета раскрыто отличие этапов создания этих систем в части изучения объекта управления, анализ схем коммуникаций, декомпозиции и реинжиниринга бизнес-процессов территориальных общин. Построен алгоритм реализации сценария разработки и внедрения (модернизации) инорормационной системы управления. Проанализирован межгосударственный стандарт «Инорормационная технология. Комплекс стандартов на автоматизированные системы. Автоматизированные системы» по утрате силы и предложены изменения с учетом особенностей органов местного самоуправления.

Ключевые слова: информационная система управления, схема коммуникаций, бизнес-процесс, орган местного самоуправления, Львовский городской совет.

The article is devoted to topical issues of the process of development and implementation of management information systems. Research in the field of development of automated information management systems, as well as practical recommendations and regulations for the development and implementation of information management systems of international economic relations are aimed at creating such systems mainly for enterprises, international and non-governmental organizations. However, the issue of management information system for public structures, territorial communities was insufficiently developed. The peculiarities of the development of management information systems for local governments are outlined. The example of Lviv City Council reveals the difference between 
the stages of creation of these systems in terms of studying the object of management, its organizational structure, defining its type, describing the functions and powers of key officials, tasks of individual departments, analyzing communication schemes, decomposition and reengineering processes of territorial communities. An algorithm for implementing the scenario of development and implementation (modernization) of management information systems is built. When creating the algorithm, the path of designing a new and unique management information system was chosen, as it would be much more expensive to transform the organizational structure of the Lviv City Council into a standardized one than to design a new one. In this way, the risks of increasing the level of conflict within the Lviv City Council can be completely avoided. The interstate standard "Information technology. A set of standards for automated systems. Automated systems "on the repeal and proposed changes to take into account the specifics of local governments. Further research should be conducted in the direction of proposals for a new version or replacement of the interstate standard on information systems to determine and plan costs for the development and implementation of management information system, their financing, finding investors and other stakeholders in changing the management information system of Lviv City Council.

Keywords: management information system, communication scheme, business process, local government, Lviv City Council.

Постановка проблеми. Сучасні умови глобалізації, цифровізації суспільних відносин, адміністративної ресооми в Україні вимагають вивчення теоретичних і практичних положень, пов'язаних із нормативно документацією на розроблення та проектування інформаційних систем управління (ICУ), управління життєвим циклом, архітектурою, впровадженням й супроводом ICУ, моделювання та аналізу бізнес-процесів. Тому проблематика удосконалення процесу розроблення і впровадження інформаційних систем управління органів місцевого самоврядування сьогодні $є$ надзвичайно актуальною.

Аналіз останніх досліджень і публікацій. Дослідженню розроблення і впровадження ІСУ, систем комунікацій в України $€$ присвяченою низка наукових праць. Вагомі внески у розроблення наукового і практичного забезпечення розвитку ІСУ зробили такі вчені, як Антоненко В.М. [1], Босак А.О. [2], Воронін А.М. [3], Гомонай-Стрижко М.В. [4], Коваленко О.С. [6], Морзе Н.В., Піх О.3. [7], Павлиш В.А. [8], Сендзюк М.А. [9], Шевчук І.Б. та багато інших.

Виділення невирішених раніше частин загальної проблеми. Проведені дослідження у сорері розроблення автоматизованих інсрормаційних управлінських систем, а також практичні рекомендації та регламенти з розроблення та впровадження інфрормаційних систем управління (ICУ) направлені на створення таких систем здебільшого для підприємств, міжнародних, неурядових організацій тощо. Однак тематика ICУ для громадських структур, територіальних громад недостатньо розроблялася.

3 огляду на це, мета статті - на прикладі органу місцевого самоврядування дослідити і показати особливості процесу розроблення та впровадження ІСУ для установ територіальних громад, розробити загальний алгоритм впровадження ІСУ для Львівської міської ради (ЛМР).
Виклад основного матеріалу дослідження. Створення та впровадження ICУ пропонуємо розглядати як проєкт, який складається 3 певних визначених етапів життєвого циклу, що починається зі задуму про ії створення. Потім ICУ проходить інтервал проєктування, перевірки й експлуатації. Закінчується цикл виводом системи з використання з причин фрізичного чи морального старіння. Відповідно до ГОСТу 34.601-90 [5] для ІСУ передбачено вісім стадій виконання робіт: орормування вимог до ICУ, розробка концепції системи, технічне завдання, ескізний проект, технічний проект, робоча документація, введення в експлуатацію, супровід системи. Кожна з цих стадій поділяється на певні етапи.

У зв'язку з тим, що зазначений міждержавний стандарт втрачає чинність 01.01.2022 р., на заміну йому має бути прийнятий новий стандарт. Нова редакція в основі ймовірно міститиме базові принципи та положення попереднього. Прийняття нової редакції $\epsilon$ можливістю визначити особливості створення та впровадження ICУ для територіальних громад, органів місцевого самоврядування.

Найбільші відмінності процесу створення та впровадження ICУ для таких типів організацій та установ мають місце на перших його стадіях. Вони і визначають, у якому напрямку в подальшому відбуватиметься реалізація стадій та етапів, адже результати обстеження об'єкту управління й обґрунтування необхідності створення системи, вивчення об'єкту управління та формування вимог користувачів до системи, створення ескізного і технічного проєктів $€$ найбільш індивідуальними характеристиками об'єкту управління.

Із вищезазначеною метою в частині обстеження об'єкту управління й обґрунтування доцільності створення ІСУ необхідно провести вивчення фрактичної організаційної структури 


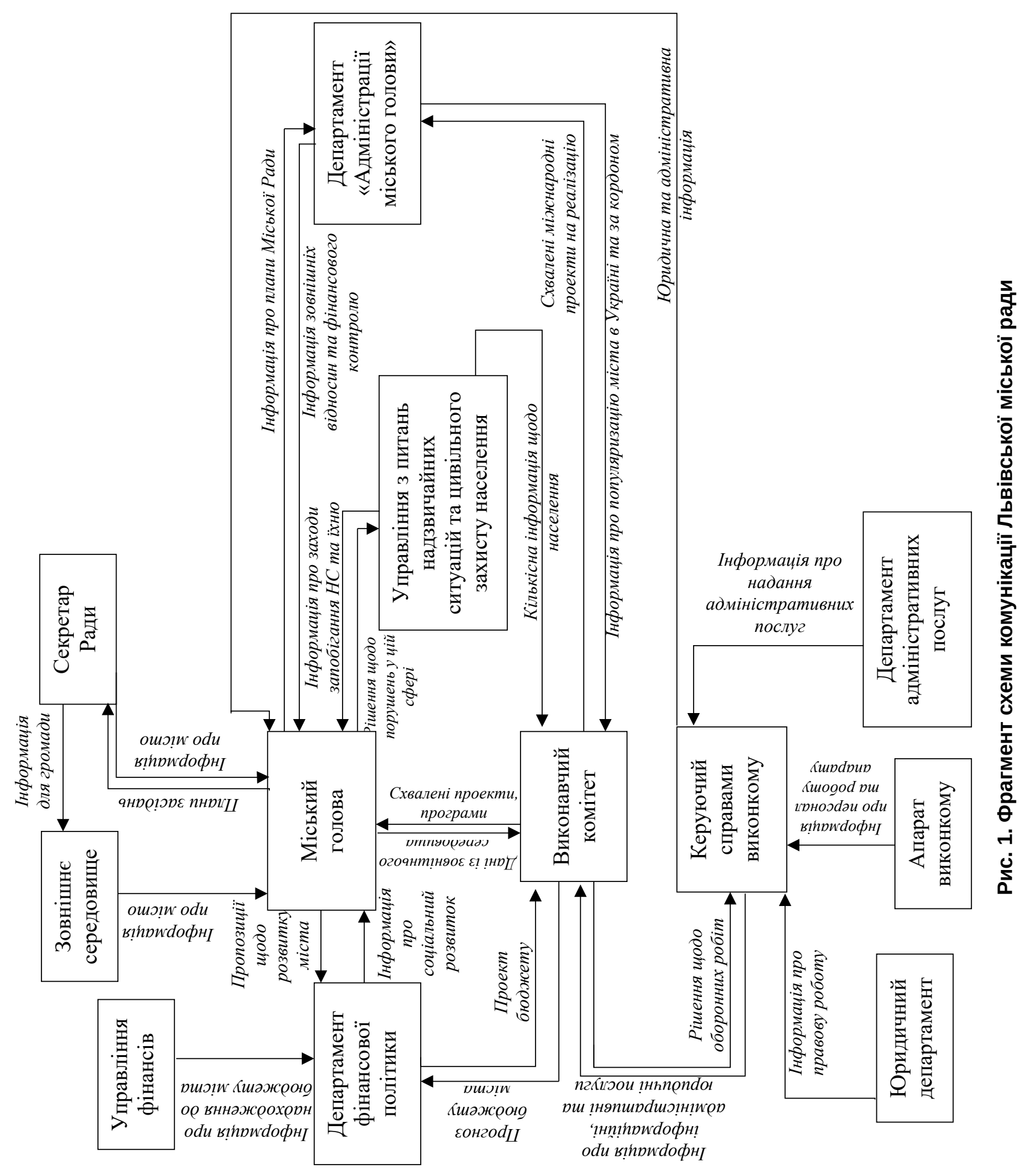


управління (ОСУ) (1), визначити вид ОСУ (2), описати фрункції та повноваження ключових посадових осіб (3), завдання окремих підрозділів організації (4), виділити недоліки фрактичної ОСУ та шляхи їх усунення в контексті створенні ICУ (5), побудувати схему комунікацій підприємства, на якій слід показати основні вхідні та вихідні інфрормаційні потоки (6), виділити основні бізнес-процеси досліджуваної організації (7) [1; 2].

У частині розроблення концептуальних варіантів та технічного завдання виходячи з результатів опису вхідних та вихідних інорормаційних потоків, вивчення бізнес-процесів необхідно сорормувати основні вимоги до майбутньої ІСУ та її головних структурних елементів (підсистем та суміжних частин), а в частині ескізного проєкту - вибрати варіант алгоритму впровадження (модернізації) ІСУ та його розробити.

Оскільки органи місцевого самоврядування $€$ великими організаціями, які за структурою докорінно відрізняються від суб'єктів господарювання, то доцільно на прикладі ЛМР окреслити ці особливості.

Так вивчення фрактичної ОСУ ЛМР [10] дало можливість визначити, що ії вид $€$ лінійним. Кожен працівник підрозділу безпосередньо підпорядковується тільки цьому керівнику (органу). У свою чергу, останній є підзвітним вищому органу. Вивчено ффункції ключових посадових осіб, їхні повноваження в контексті права використання ресурсів та відповідальність.
Для цілісності розуміння об'єкта управління доцільно для кожного структурного підрозділу дослідити завдання, його ресурсне забезпечення, результати діяльності та показники, якими можна її вимірювати. У результаті буде виділено недоліки фрактичної ОСУ та ймовірні шляхи їх усунення, що будуть враховані у процесі створення та впровадження ICУ.

На наступному етапі сорормовані схеми комунікацій ЛМР (рис. 1) та оцінені рівні ефрективності системи комунікацій підприємства в розрізі розрізі основних вхідних і вихідних інформаційних потоків щодо джерела/отримувача інорормації, сутності інфрормації та типу документів, якими вони реалізуються. Враховуючи відносну складність комунікацій ЛМР, на рис. 1 зображено лише основні учасники та зв'язки.

На рисунку можна побачити, що основними підрозділами та особами $є$ міський голова, виконавчий комітет та керуючий справами виконкому. А біля кожної стрілки - сутність інформації, що надходить до/з даного підрозділу чи особи.

Вивчення бізнес-процесів ЛМР пропонуємо здійснювати задопомогою використання методології структурного аналізу та проектування SADT (Structured Analysis and Design Technique), яка запропонована Дугласом Т.Фоссом і покладена в основу відомих американських стандартів IDEF (Integration Definition for Information Modeling), за допомогою яких можна створювати фрункціональні та інсрормаційні моделі [2; 6]. У результаті

Рішення про відкриття Львівського Різдвяного Ярмарку та підготовку до нього

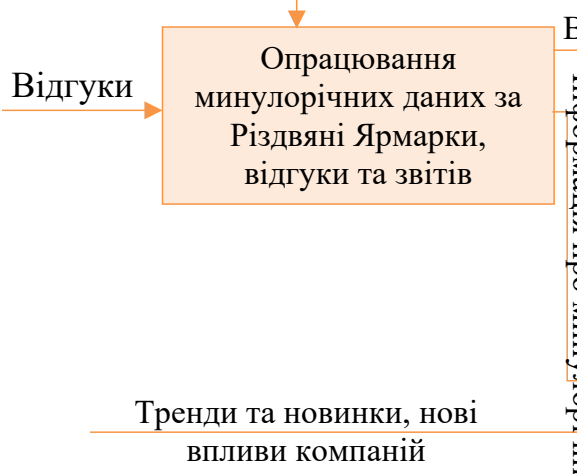

Відгуки та побажання клієнтів
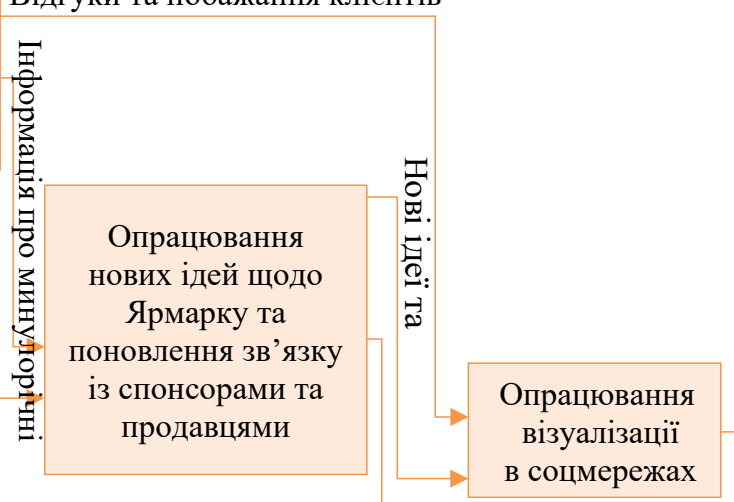

Готова реклама та візуалізація

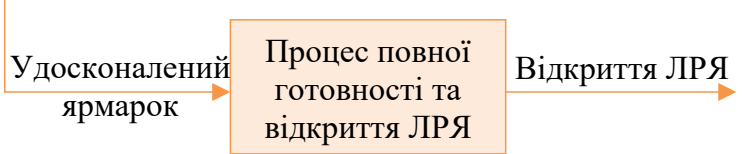

Рис. 2. SADT-діаграма відкриття Львівського Різдвяного Ярмарку 


\section{Таблиця 1}

Основні вимоги (базові функції) до фрагменту підсистем ІСУ Львівської міської ради, що є специфічними для органів місцевого самоврядування

\begin{tabular}{|c|c|c|c|}
\hline $\begin{array}{l}\text { № } \\
3 / \Pi\end{array}$ & Підсистеми ICУ & Базові фрункції & $\begin{array}{c}\text { Tехнічне та програмне } \\
\text { забезпечення }\end{array}$ \\
\hline 1 & $\begin{array}{c}\text { Управління } \\
\text { зовнішньо- } \\
\text { економічною } \\
\text { діяльністю }\end{array}$ & $\begin{array}{l}\text { - Складання коротко-, середньо- та } \\
\text { довгострокових планів розвитку ЗЕД; } \\
\text { - Організування роботи працівників по } \\
\text { підрозділах та ділянках роботи; } \\
\text { - Узгдження та координування всіма } \\
\text { підрозділами у ЛМР; } \\
\text { - Аналізувати результати та оцінювати } \\
\text { ефективність роботи у сфрері ЗЕД }\end{array}$ & $\begin{array}{l}\text { Нематеріальні - ліцензії, } \\
\text { сертифікати на право } \\
\text { здійснення ЗЕД; } \\
\text { Інфрормаційні - сукупність } \\
\text { зовнішньої та внутрішньої } \\
\text { діяльностей; Програмні - } \\
\text { OC Microsoft Windows 11, } \\
\text { Iнтернет, Fex.net чи Google } \\
\text { Диск. }\end{array}$ \\
\hline 2 & $\begin{array}{c}\text { Управління } \\
\text { інноваційною } \\
\text { та проектною } \\
\text { діяльністю }\end{array}$ & $\begin{array}{l}\text { - Аналіз проектів та дослідження } \\
\text { інновацій; } \\
\text { - Бізнес-плани для проектів; } \\
\text { - Розроблення прогнозів науково- } \\
\text { технічного розвитку; } \\
\text { - Обґрунтування та вибір основних } \\
\text { напрямів інноваційної діяльності }\end{array}$ & $\begin{array}{l}\text { Нематеріальні - патенти, } \\
\text { ліцензії, сертиорікати на } \\
\text { право займатися проектною } \\
\text { діяльністю; Кадрові - фахівці } \\
\text { у даній сфері; Програмні - } \\
\text { документація, щодо проектів } \\
\text { та інновацій. }\end{array}$ \\
\hline 3 & $\begin{array}{c}\text { Управління } \\
\text { безпекою міста }\end{array}$ & $\begin{array}{l}\text { - Моніторинг заходів з питань } \\
\text { законності, правопорядку, безпеки, } \\
\text { охорони прав та інтересів мешканців } \\
\text { та гостей на території м. Львова; } \\
\text { - Виявлення, попередження та } \\
\text { припинення правопорушень у межах } \\
\text { наданих повноважень; } \\
\text { - Підготовка і подання на розгляд } \\
\text { міської ради стратегії розвитку } \\
\text { м. Львова у просрільній сфрері, } \\
\text { пропозицій для складання і реалізації } \\
\text { місцевих програм. }\end{array}$ & $\begin{array}{l}\text { Iнсрормаційні - сукупність } \\
\text { зовнішньої та внутрішньої } \\
\text { діяльностей - особливо } \\
\text { зовнішньої інфрормації про } \\
\text { становище міста з середини; } \\
\text { Кадрові - перший захисник } \\
\text { Міського голови; Програмні } \\
\text { - Oпераційна система } \\
\text { Microsoft Windows 11, } \\
\text { Інтернет, Fex.net чи Google } \\
\text { Диску, жорсткі диски. }\end{array}$ \\
\hline 4 & $\begin{array}{c}\text { Управління } \\
\text { гуманітарних } \\
\text { питань }\end{array}$ & $\begin{array}{l}\text { - Керування закладами, культури, які } \\
\text { входять до комунальної власності } \\
\text { міської ради; } \\
\text { - Моніторинг розвитку української та ін. } \\
\text { національних культур, укріпленню } \\
\text { міжнаціональних культурних зв'язків; } \\
\text { - Забезпечення реалізації на території } \\
\text { міста державної політики молоді, сім'ї, } \\
\text { масових заходів. }\end{array}$ & $\begin{array}{l}\text { Нематеріальні - ліцензії, } \\
\text { сертифрікати; Програмні - } \\
\text { Операційна система Мicrosoft } \\
\text { Windows 11, Інтернет, Fex. } \\
\text { net чи Google Диск, жорсткі } \\
\text { диски; Кадрові - фрахівці у } \\
\text { даній сфрері; Інфрормаційні } \\
\text { ресурси - демографрічні, } \\
\text { прцездатні тощо. }\end{array}$ \\
\hline
\end{tabular}

можна здійснити декомпозицію та реінжиніринг окремих бізнес-процесів. Як приклад, на рис. 2 зображено SADT-діаграму щодо рішення ЛМP про відкриття Львівського Різдвяного Ярмарку та підготовку до нього.

Використовуючи зазначену методологію SADT-діаграм можна отримати декомпозицію більшості бізнес-процесів організації та, за потреби, здійснити їх реінжиніринг.

На етапі формування технічного завдання на створення та впровадження ICУ виходячи 3 результатів опису місії, цілей, вхідних та вихідних інорормаційних потоків, декомпозиції бізнес-процесів доцільно ссрормувати основні вимоги до майбутньої ІСУ та її головних структурних елементів (підсистем та суміжних частин) (табл. 1).
На етапі розроблення алгоритму впровадження (модернізації) ІСУ на основі використання отриманої в попередніх етапах інфрормації про діяльність ЛМР можна обрати варіант та розробити алгоритм впровадження (модернізації) ICУ.

У ЛМР достатньо хороша автоматизація управлінських робіт як для масштабної та багатофункціональної структури. У ЛМР $\epsilon$ проблема із своєчасністю інформації, оскільки департаменти та інші додаткові установи не мають прямої комунікації між собою і все відбувається через керівників вищих ланок, а це все потребує часу.

У ЛМР ОСУ $є$ великою, тому для впровадження рекомендується створення унікальної 


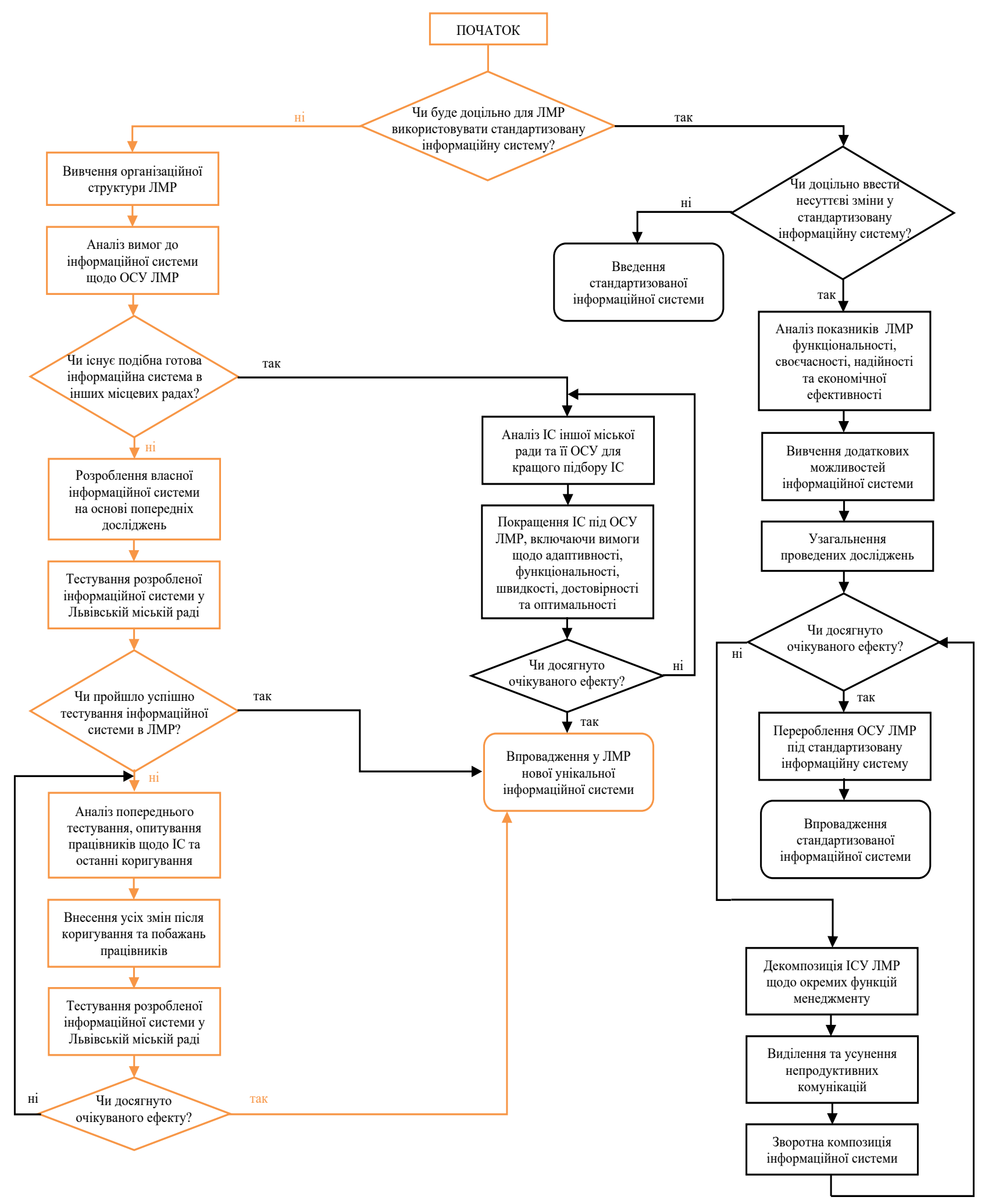

Рис. 3. Загальний алгоритм впровадження ICУ у ЛМР

ICУ, щоб уникнути великих витрат на переорганізацію ОСУ, що є більш затратним, аніж спроектувати нову і унікальну ІСУ. Побудований алгоритм вибору впровадження інсоормаційної системи у Львівській міській раді показано на рис. 3. Для розуміння алгоритму кращий варіант для ЛМР, а саме проектування нової унікальної інфрормаційної системи управління, позначено кольором.

Висновки. При створенні алгоритму було обрано шлях проектування нової та унікальної ІСУ, оскільки переробити ОСУ ЛМР під стандартизовану було б набагато дорожче, аніж спро- 
ектувати нову. Тим більше, що при виборі цього шляху, ми повністю уникаємо ризиків збільшення рівня конфрліктності всередині ЛМР.

Подальші дослідження доцільно проводити в напрямку пропозицій для нової редакції чи заміни міждержавного стандарту з інсрормаційних систем щодо визначення і планування витрат з розроблення та впровадження ICУ, їх орінансування, пошуку інвесторів та інших зацікавлених осіб у зміні ІСУ ЛМР.

\section{СПИСОК ВИКОРИСТАНИХ ДЖЕРЕЛ:}

1. Антоненко В.М., Мамченко С.Д., Рогушина Ю.В. Сучасні інфрормаційні системи і технології: управління знаннями. Ірпінь : Нац. університет ДПС України, 2016.

2. Босак А.О., Босак О.А. Модель комунікаційного циклу машинобудівного підприємства. Вісник Національного Університету “Львівська політехніка". Серія "Менеджмент та підприємництво в Україні: етапи становлення і проблеми розвитку". 2010. № 682. С. 23-35.

3. Воронін А.М., Зіатдінов Ю.К., Климова А.С. Інформаційні системи прийняття рішень. Київ : НАУ-друк, 2009.

4. Гомонай-Стрижко М.В., Якімцов В.В. Інформаційні системи та технології на підприємстві. Львів : НЛтУ, 2014. URL: http://ep.nltu.edu.ua/images/Kafedra_EP/Kafedra_EP_PDFs/kl_isitp.pdf

5. ГОСТ 34.601-90 Інформаційна технологія. Комплекс стандартів на автоматизовані системи. Автоматизовані системи. Стадії створення : Постанова від 29.12.1990 р. № 3469. URL: http://online.budstandart.com/ua/ catalog/doc-page.html?id_doc $=53626$

6. Коваленко О.С., Добровська Л.М. Проектування інформаційних систем: Загальні питання теорії проектування IC. Електронні текстові дані (1 фрайл: 2,02 Мбайт). Київ : КПІ ім. Ігоря Сікорського, 2020.

7. Морзе Н.В., Піх О.3. Інформаційні системи. Івано-Франківськ : ЛілеяНВ, 2015.

8. Павлиш В.А., Гліненко Л.К. Основи інсрормаційних технологій і систем. Львів : Видавництво Львівської політехніки, 2013.

9. Сендзюк М.А. Інформаційні системи і технології в економіці. Київ : КНЕУ, 2010.

10. Структура виконавчих органів Львівської міської ради. URL: https://www8.city-adm.lviv.ua/inTEAM/ Uhvaly.nsf/91c21bb29b2b4f47c22571340037f910/247ac0594512f699c22580fe00253142/\$FILE/додаток.pdf

\section{REFERENCES:}

1. Antonenko, V.M., Mamchenko, S.D. \& Rogushina, Yu.V. (2016) Suchasni informatsiyni systemy i tekhnolohiyi: upravlinnya znannyamy [Modern information systems and technologies: knowledge management]. Irpen: Nat. University of the State Tax Service of Ukraine. (in Ukrainian)

2. Bosak, A.O. \& Bosak, O.A. (2010) Model' komunikatsiynoho tsyklu mashynobudivnoho pidpryyemstva [Model of communication cycle of machine-building enterprise]. Bulletin of the National University "Lviv Polytechnic" Series "Management and Entrepreneurship in Ukraine: Stages of Formation and Problems of Development", 682, 23-35. (in Ukrainian)

3. Voronin, A.M., Ziatdinov Y.К. \& Климова А.С. (2009) Informatsiyni systemy pryynyattya rishen' [Information systems for decision making]. Kyiv: NAU-print. (in Ukrainian)

4. Homonai-Strizhko, M.V. \& Yakimtsov V.V. (2014) Informatsiyni systemy ta tekhnolohiyi na pidpryyemstvi [Information systems and technologies at the enterprise]. Lviv: NLTU. Retrieved from: http://ep.nltu.edu.ua/images/ Kafedra_EP/Kafedra_EP_PDFs/kl_isitp.pdf (in Ukrainian)

5. GOST 34.601-90 Informatsiyna tekhnolohiya. Kompleks standartiv na avtomatyzovani systemy. Avtomatyzovani systemy. Stadiyi stvorennya Information technology [A set of standards for automated systems. Automated systems. Stages of creation] / Resolution of 29.12.1990 № 3469. Retrieved from: http://online.budstandart.com/ua/ catalog/doc-page.html?id_doc=53626 (in Ukrainian)

6. Kovalenko, O.C. \& Dobrovska, L.M. (2020) Proektuvannya informatsiynykh system: Zahal'ni pytannya teoriyi proektuvannya IS [Information systems design: General issues of IP design theory]. [Electronic resource]. Electronic text data (1 file: $2.02 \mathrm{MB}$ ). Kyiv: KPI named after Igor Sikorsky. (in Ukrainian)

7. Morse, N.W. \& Pih O.Z. (2015) Informatsiyni systemy [Information systems]. Ivano-Frankivsk: LileyaNV. (in Ukrainian)

8. Pavlish, V.A. \& Glinenko, L.K. (2013) Osnovy informatsiynykh tekhnolohiy i system [Fundamentals of information technology and systems]. Lviv: Lviv Polytechnic Publishing House. (in Ukrainian)

9. Sendziuk, M.A. (2010) Informatsiyni systemy i tekhnolohiyi v ekonomitsi [Information systems and technologies in economics]. Kyiv: KNEU. (in Ukrainian)

10. The structure of the executive bodies of the Lviv City Council. Retrieved from: https://www8.city-adm.Iviv.ua/ inTEAM/Uhvaly.nsf/91c21bb29b2b4f47c22571340037f910/247ac0594512f699c22580fe00253142/\$FILE/додаток.pdf (in Ukrainian) 